\title{
The relationship between thyroidectomy complications and body mass index
}

\author{
(D) Mehmet Üstün ${ }^{1}$ \\ (iD) Avni Can Karaca² \\ (iD) ihsan Biro ${ }^{3}$ \\ (iD) Gülberk Uslu' \\ Semra Demirli Atıcl \\ (iD) Cengiz Aydin ${ }^{1}$
}

1. University of Health Sciences Tepecik Training and Research Hospital, Department of General Surgery, Izmir, Turkey 2. Izmir University of Economics Faculty of Medicine, Department of General Surgery, Izmir, Turkey 3. 25 Aralik State Hospital Department of General Surgery, Gaziantep, Turkey

\section{SUMMARY}

INTRODUCTION: Obesity is a growing public health problem associated with many comorbid diseases. The aim of this study was to evaluate the relationship between body mass index and complications of thyroidectomy.

METHODS: Patients who underwent total thyroidectomy between January 2015 and December 2018 were enrolled. Patients were divided into two groups, i.e., BMI <25 (group A) and BMl 25 (group B). Demographics, operative time, and complications were retrospectively reviewed.

RESULTS: The study included 145 patients (66 in Group A and 79 in Group B). There was no significant difference between the two groups in terms of age ( $p=0.330)$ and gender $(p=0.055)$. No surgical site infection and bleeding complications were observed in any patients. The mean operative time was 148.4 minutes (90-235) in Group A and 153.4 minutes (85-285) in Group B ( $p=0.399)$. Transient hypocalcemia was observed in $25(37.9 \%)$ patients in group A, and $23(29.1 \%)$ patients in Group $B(p=0.291)$. Permanent hypocalcemia was not observed in any patient in group $A$, and in 2 patients in Group $B(2.5 \%)(p=0.501)$. Transient recurrent nerve palsy was observed in $1(1.5 \%)$ patient in Group A and in $3(3.8 \%)$ patients in Group B ( $p=0.626)$. None of the patients had permanent recurrent nerve palsy. Parathyroid autotransplantation was performed on 1 patient $(1.5 \%)$ in group $A$ and on $7(8.9 \%)$ patients in Group $B(p=0.055)$.

CONCLUSION: We think there is no relationship between a high BMI and thyroidectomy complications, and surgery can also be performed safely in this patient group.

KEYWORDS: Thyroidectomy. Thyroid Gland/surgery. Postoperative Complications. Body Mass Index.

\section{INTRODUCTION}

Obesity is a growing public health problem associated with many comorbid diseases. The number of patients with a high body mass index (BMI) undergoing surgical procedures increases with the increasing obesity rate. Considering endocrine surgery, several studies have reported the relationship between obesity and thyroid cancer or hyperparathyroidism. There are scarce studies reporting the safety and complications of endocrine surgery in high body mass index patients $^{1-7}$. The aim of this study was to evaluate the

DATE OF SUBMISSION: 06-May-2020

DATE OF ACCEPTANCE: 11-Jul-2020

CORRESPONDING AUTHOR: İhsan Birol

Güney Mahallesi 1140/1 Sokak No: 1 Yenişehir Konak İzmir, Türkiye - Sağlık Bilimleri Üniversitesi Tepecik Eğitim ve Araştırma Hastanesi

Sağlık Bilimleri Üniversitesi Te - İzmir - Turkey - 35180. Tel:+905363624585 - Fax: +902324330756

E-mail: ihsanbirol@gmail.com 
relationship between body mass index and thyroidectomy complications including parathyroid autotransplantation rates among other parameters in other studies.

\section{METHODS}

Patients who underwent total thyroidectomy in our center between January 2015 and December 2018 were enrolled in this study. Patients who underwent thyroidectomy for recurrence, hemithyroidectomy, completion thyroidectomy, parathyroidectomy, and lymph node dissection were excluded. Neuromonitoring is not a routine practice in our center due to technical and financial reasons. The cases operated with neuromonitoring were also excluded from the study. All operations were performed by two surgeons. The surgical technique involved conventional standard ligation (clamping-tie) and vascular closure devices for hemostasis. Parathyroid glands were identified and dissected within their capsules maintaining vascularization as much as possible. The recurrent nerve was always identified at the laryngeal penetration point. Parathyroid autotransplantation into the sternocleidomastoid muscle or strap muscles was used as a salvage procedure in case of the devascularization of the glands.

Body mass index (BMI) was calculated using the formula [weight $(\mathrm{kg}) /$ height $\left.\left(\mathrm{m}^{2}\right)\right]$.

Patients were divided into two groups, BMI $<25$ and $\mathrm{BMI} \geq 25$. Demographics, American Society of Anesthesiologists (ASA) scores, operation time (minutes), postoperative bleeding complications, parathyroid autotransplantation rates, surgical site infection, postoperative serum calcium level, postoperative recurrent nerve palsy, and length of stay were recorded and retrospectively analyzed.

Hypocalcemia was defined as a postoperative serum calcium level below $8 \mathrm{mg} / \mathrm{dl}$. Hypocalcemia lasting less than 6 months was defined as transient, and lasting more than 6 months was defined as permanent.

Recurrent nerve palsy was diagnosed with indirect laryngoscopy which was performed on patients with dysphonia, dyspnea, and swallowing disorders. Recurrent laryngeal nerve palsy that was persistent for 6 months and documented by laryngoscopy was considered as permanent palsy.

Approval from the institutional research ethics board was obtained (decision number 2019/12-2).

\section{Statistical Analysis}

The $25^{\text {th }}$ version of the "Statistics Package for Social Sciences" by International Business Machines Corporation (IBM) (New York, United States) was utilized for statistical analysis. Fisher's exact t-test was used for comparing discrete variables and one-way ANOVA was used for continuous variables. Logistic regression was used for multivariate analysis. A p-value of less than 0.05 was considered statistically significant.

\section{RESULTS}

A total of 145 patients were enrolled. One hundred twenty-five were female (86.2\%) and 20 were male (13.8\%). There were 66 patients (45.5\%) in the BMI $<25$ group and 79 patients (54.5\%) in the $\mathrm{BMI} \geq 25$ group. The mean age in the BMI $<25$ group was 43.9 (17-73) years and the mean age in the BMI $\geq 25$ group was 48.2 (24-74) years. In the BMI $<25$ group, 5 (7.5\%) patients were male and $61(92.5 \%)$ were female. In the $\mathrm{BMI} \geq 25$ group, $15(19 \%)$ patients were male and $64(81 \%)$ were female. There was no statistically significant difference between the two groups in terms of age $(p=0.330)$ and gender $(\mathrm{p}=0.055)$. No surgical site infection and postoperative hematoma/bleeding complications were observed in any patients in both groups.

When both groups were compared in terms of operative time, the mean operative time was 148.4 minutes (90-235) in the BMI <25 group and 153.4 minutes (85-285) in the $B M I \geq 25$ group ( $p=0.399)$.

In the BMI <25 group, 25 (37.9\%) patients had transient hypocalcemia postoperatively, whereas in the $\mathrm{BMI} \geq 25$ group, 23 (29.1\%) patients had transient hypocalcemia $(p=0.291)$. Permanent hypocalcemia was not observed in any patient in the BMI $<25$ group; in the $\mathrm{BMI} \geq 25$ group, it was observed only in 2 patients $(2.5 \%)(p=0.501)$. There were no statistically significant differences between the two groups in terms of postoperative transient and permanent hypocalcemia rates.

Transient recurrent nerve palsy was observed in $1(1.5 \%)$ patient in the BMI <25 group and in $3(3.8 \%)$ patients in the BMI $\geq 25$ group. None of the patients had permanent recurrent nerve palsy. there was no statistically significant difference between the two groups in terms of postoperative recurrent nerve palsy $(\mathrm{p}=0.626)$.

In the BMI <25 group, parathyroid autotransplantation was performed on 1 patient (1.5\%); in the $\mathrm{BMI} \geq 25$ group, it was performed on 7 (8.9\%) patients. Although 
the ratio seems higher in the $\mathrm{BMI} \geq 25$ group, there was no statistically significant difference between the two groups in terms of performing parathyroid autotransplantation $(\mathrm{p}=0.055)$

No statistically significant difference was found between the two groups in terms of any parameter examined both with univariate and multivariate analyses.

TABLE 1. DEMOGRAPHIC AND CLINICAL CHARACTERISTICS OF PATIENTS CLASSIFIED INTO VARIOUS BMI GROUPS

\begin{tabular}{|c|c|c|c|}
\hline & $\begin{array}{l}\text { BMI <25 } \\
\text { group } \\
\mathrm{n}: 66\end{array}$ & $\begin{array}{l}\text { BMI } \geq 25 \\
\text { group } \\
\mathrm{n}: 79\end{array}$ & P-value \\
\hline Age (Mean) & 43.97 & 48.28 & 0.330 \\
\hline $\begin{array}{l}\text { Gender }(n, \%) \\
\text {-Male } \\
\text {-Female }\end{array}$ & $\begin{array}{l}5(7.6) \\
61(92.4)\end{array}$ & $\begin{array}{l}15(19) \\
64(81)\end{array}$ & 0.055 \\
\hline $\begin{array}{l}\text { ASA Score }(n, \%) \\
\text {-ASA1 } \\
\text { - ASA2 } \\
\text { - ASA } 3 \\
\text {-ASA } 4\end{array}$ & $\begin{array}{l}7(10.6) \\
54(81.8) \\
5(7.6) \\
0\end{array}$ & $\begin{array}{l}11(14) \\
64(81) \\
4(5) \\
0\end{array}$ & 0.451 \\
\hline Transient hypocalcemia (n,\%) & $25(37.9)$ & 23 (29.1) & 0.291 \\
\hline $\begin{array}{l}\text { Permanent hypocalcemia } \\
(\mathrm{n}, \%)\end{array}$ & 0 & $2(2.5)$ & 0.501 \\
\hline $\begin{array}{l}\text { Transient recurrent nerve } \\
\text { palsy }(n, \%)\end{array}$ & $1(1.5)$ & $3(3.8)$ & 0.626 \\
\hline $\begin{array}{l}\text { Permanent recurrent nerve } \\
\text { palsy }(n, \%)\end{array}$ & 0 & 0 & \\
\hline $\begin{array}{l}\text { Operative time (Mean, } \\
\text { minutes) }\end{array}$ & 148.4 & 153.4 & 0.399 \\
\hline $\begin{array}{l}\text { Parathyroid autotransplanta- } \\
\text { tion }(n, \%)\end{array}$ & $1(1.5)$ & $7(8.9)$ & 0.055 \\
\hline
\end{tabular}

\section{DISCUSSION}

The increasing prevalence of obesity also brings an increase in the number of patients with a high body mass index undergoing general surgical procedures. This led us to investigate the relationship between complications of general surgical procedures and a high body mass index.

Thyroidectomy is one of the most common general surgical procedures. Buerba et al. ${ }^{4}$ reported an increased rate of wound site complications in obese and morbidly obese patients, and also urinary complications in morbidly obese patients in their study of 26864 patients. The same study showed the relationship between obesity and wound site complications and longer durations of surgery after parathyroidectomy. The authors noted that despite the statistical significance, the difference might not be clinically significant as the complications were rare, they did not prolong the hospital admission and required reoperation. They concluded that thyroidectomy and parathyroidectomy can be performed safely in this patient group with appropriate surgical decision making. Our study found no wound site infections with a smaller patient group.

Our study found no statistically significant difference between patients with normal and high BMI in terms of wound site infection, hematoma, transient or permanent hypocalcemia, or recurrent nerve injury. Finel et al. ${ }^{5}$ reported similar results about complications but prolonged surgery in patients with a high BMI. They attributed this difference to bad exposure due to shorter and wider neck, and harder dissection of the parathyroid tissue in adipose tissue in this patient group.

Milone et al. ${ }^{6}$ also reported similar findings and longer duration of operation in patients with $\mathrm{BMI} \geq 25$ in their series of 266 patients with similar comments about anatomy and patient positioning. The harder dissection of the parathyroid tissue in the adipose tissue can also result in a devascularization of the parathyroid glands. We, therefore, included the need for parathyroid autotransplantation to our variables and found a higher rate (1.5\% vs $8.9 \%)$ in patients with a high BMI. However, the difference was not statistically significant and did not result in a longer operative time.

Hypocalcemia, either temporary or permanent, is a common and important problem after thyroidectomy. Current metanalyses report a rate of 19\%-38\% transient and 0\%-3\% permanent hypocalcemia after thyroidectomy ${ }^{8}$. Our study revealed similar rates in both groups with no increase in patients with a high BMI.

Recurrent nerve palsy is one of the most serious complications of thyroidectomy. Current literature reveals a rate of $9.8 \%(1.4 \%-38.4 \%)$ transient and $2.3 \%$ (0\%-18.6\%) permanent recurrent nerve palsy after thyroidectomy ${ }^{9}$. Our study found similar rates for temporary injury and no cases of permanent ones. The latest paper about obesity and thyroidectomy was published in 2019 by Farag et al. ${ }^{7}$ and it also reports no relationship between obesity and thyroidectomy complications. Our study found similar results with previous reports. The retrospective design and number of patients are limitations of our study.

\section{CONCLUSION}

We think there is no relationship between a high BMI and thyroidectomy complications, and surgery can also be performed safely in this patient group. 
Multicenter prospective studies and metanalyses can increase knowledge in the subject.

\section{Financial Disclosure}

The authors declare that this study has received no financial support.

\section{Conflicts of Interest}

No conflict of interest was declared by any of the authors.

\section{Author's Contribution}

MU and IB designed and prepared the study. MU wrote the article. SDA and GU collected the patients' data. IB and ACK helped draft the study. IB, ACK, MU, $\mathrm{GU}$, and SDA participated in the surgical and medical treatment of the patients. CA designed the study, participated in the design and coordination, and helped draft the study. All authors have read and approved the last version of the article.

\section{RESUMO}

INTRODUÇÃo: A obesidade é um crescente problema de saúde pública associado a muitas doenças comórbidas. O objetivo deste estudo foi avaliar a relação entre o índice de massa corporal e as complicações da tireoidectomia.

MÉTODOS: Os pacientes submetidos à tireoidectomia total entre janeiro de 2015 e dezembro de 2018 foram incluídos. Os pacientes foram divididos em dois como IMC <25 (grupo A) e IMC $\geq 25$ (grupo B). Demografia, tempo operatório e complicações revisadas retrospectivamente.

RESULTADOS: O estudo incluiu 145 pacientes (66 no grupo A e 79 no grupo B). Não houve diferença significativa entre os dois grupos em termos de idade $(p=0,033)$ e sexo $(p=0,055)$. Nenhuma infecção do sítio cirúrgico e complicações hemorrágicas foram observadas em nenhum paciente. O tempo operatório médio foi de 148,4 minutos (90-235) no grupo A e 153,4 minutos (85-285) no grupo B ( $p=$ 0,399). Hipocalcemia transitória foi observada em 25 (37,9\%) pacientes do grupo $A$ e 23 (29,1\%) do grupo B ( $p=0,291)$. Hipocalcemia permanente não foi observada em nenhum paciente do grupo $A$ e em 2 pacientes do grupo $B(2,5 \%)(p=0,501)$. Paralisia nervosa recorrente transitória foi observada em $1(1,5 \%)$ paciente no grupo $A$ e em $3(3,8 \%)$ pacientes no grupo $B(p=0,626)$. Nenhum dos pacientes apresentou paralisia nervosa recorrente permanente. O autotransplante de paratireóide foi realizado em 1 paciente (1,5\%) no grupo A e em 7 (8,9\%) pacientes no grupo B ( $p=0,055)$.

CONCLUSÃO: Acreditamos que não há relação entre um IMC alto e as complicações da tireoidectomia e a cirurgia pode ser realizada com segurança também neste grupo de pacientes.

PALAVRAS-CHAVE: Tireoidectomia. Glândula Tireoide/cirurgia. Complicações Pós-Operatórias. Índice de Massa Corporal.

\section{REFERENCES}

1. Bolland MI, Grey AB, Gamble GD, Reid IR. Association between primary hyperparathyroidism and increased body weight: a meta-analysis. J Clin Endocrinol Metab. 2005;90(3):1525-30.

2. Shin $\mathrm{HY}$, Jee $\mathrm{YH}, \mathrm{Cho}$ ER. Body mass index and incidence of thyroid cance in Korea: the Korean Cancer Prevention Study-II. | Cancer Res Clin Oncol. 2017;143(1):143-9.

3. Kwon H, Chang Y, Cho A, Ahn J, Park SE, Park CY, et al. Metabolic obesity phenotypes and thyroid cancer risk: a cohort study. Thyroid. 2019;29(3):349-58

4. Buerba R, Roman SA, Sosa A. Thyroidectomy and parathyroidectomy in patients with high body mass index are safe overall: analysis of 26,864 patients. Surgery. 2011;150(5):950-8.

5. Finel JB, Mucci S, Branger F, Venara A, Lenaoures P, Rodien P, et al. Thyroidectomy in patients with a high BMI: a safe surgery? Eur | Endocrinol. 2014;171(1):99-105
6. Milone M, Musella M, Conzo G, Campana G, De Filippo D Coretti G et al. Thyroidectomy in high body mass index patients: a single center experience. Int | Surg. 2016;28(Suppl 1):S38-41.

7. Farag M, Ibraheem K, Garstka ME, Shalaby H, DuCoin C, Killackey M, et al. Thyroid surgery and obesity: cohort study of surgical outcomes and local specific complications. Am | Surg. 2019;217(1):142-5.

8. Edafe O, Antakia R, Laskar N, Uttley L, Balasubramanian SP. Systematic review and meta-analysis of predictors of post-thyroidectomy hypocalcaemia. Br J Surg. 2014;101(4):307-20.

9. Jeannon IP, Orabi AA, Bruch GA, Abdalsalam HA, Simo R. Diagnosis of recurrent laryngeal nerve palsy after thyroidectomy: a systematic review. Int | Clin Pract. 2009;63(4):624-9. 